\title{
Wildlife population, structure and reproduction based on hunters' returns to a bush meat market in Abeokuta, Ogun state, Nigeria
}

\author{
Muideen Alade Yis au ${ }^{1} *$ Israel Oluyinka Oloyede Osunsina ${ }^{1 *}$ Samuel Akinyele Onadeko $^{1}$ \\ ${ }^{1}$ Department of Forestry and Wildlife Management, College of Environmental Resources Management, Federal University of Agriculture, Abeokuta, Ogun State, \\ Nigeria. \\ *Author for correspondence: osunsinaisrael@ yahoo.com \\ Received: November 2018 / Accepted: March 2019 / Published: March 2019
}

\begin{abstract}
Assessment of the population structure and reproductive status based on hunters' returns to bush meat market were carried out in Ogun state, Nigeria. Information on animal species was collected before they are dissected or processed; names of species, age class, sex, weight and sources. After dissection, its reproductive status viz number of foetus and stages of development were observed. The data collected covered a period of three months. The result from the study showed that nine hundred and eighty-nine animals were returned by hunters to the market within the period. The highest hunters' returns occurred at week four while the highest returns were also during the first four weeks. Canerat (Thryonomys swinderianus) and Maxwell duiker (Cephalophus maxwelli) were animals with the highest frequency returned. The result shows that 342 fetuses were recorded from all the species. The highest of fetuses was from Cane rat and Maxwell duiker. Seven orders of mammals were discovered in the population and rodentia had the highest percentage followed by artiodactyla. In terms of sex structure of the wild animal returned, female had the highest population (558) than male which has 431 animals. Also, for the age class structure, the adult had the highest frequency and percent than the sub-adult and juvenile. The patterns of returns by hunters from various sources showed that the highest animal return was from Tibo (157) and the least from Oba (8). The highest mean weight of animals returned was $19.0 \pm 0.00 \mathrm{~kg}$ and the least mean weight of animal was $0.46 \pm 0.22 \mathrm{~kg}$. It is therefore, recommended that wildlife resources should be treated as an asset to be conserved, managed and given emphasis in land management for the benefit of all humanity. Vigorous efforts towards checking indiscriminate hunting of animals of all sexes and reproductive conditions must be pursued.
\end{abstract}

Keywords:Wildlife population, Wildlife structure, Reproduction, Bush meat market.

\section{Introduction}

It is on record that bush meat extraction in Africa is exceptionally high and West Africa in particular is noted for severe hunting of game animals, leading to extinctions of some animal species (Oates et al. 2001; Brashares et al. 2001). Studies has shown that illegal hunting occurs mostly in the dry season (Holmern et al. 2007; Nyahongo et al. 2009); and people hunt with dogs and snares trap (Holmernet al. 2006). This is because bush meat is substantially cheaper than domestic meat (Ndibalema and Songorwa 2007).

The supply of bush meat from the wild no doubt serve as the only possible measure to bridge the gap between livestock production and human population growth most especially in the developing countries where it is cheaper and more readily available than beef, pork or poultry (Onadeko et al. 2001; Ayodele et al. 1999). Wildlife exploitation as bush meat is not limited to Nigeria, it is a common scenario in Africa (Onadeko et al. 2001). In many countries in Africa; West Africa (Brashares et al. 2014, Waite, 2007), Central Africa (Fa \&Yuste, 2001, Rist et al. 2008), East Africa (Kiringe et al. 2017; Lwanga 2006; Olupot et al. 2009; Loibooki et al. 2002; Thirgood et al. 2007) wildlife remain the chief traditional source of protein.

The bush meat trade is perceived as a major threat to wild animal population in the tropics. There is little information in the literature about the organization of the trade, thus hindering the development of effective conservation policy (Guy et al. 2004).

Although bush meat trade is socio-economically important, many authors such as Ape Alliance 1998; de Merode et al. 2003; Fa et al. 2003; Okiwelu et al. 2009 have decried the unsustainable and illegal hunting and harvesting of bush meat for commercial purposes as a serious threat to the populations of these wild animals, including trade in them.

Hunting for bush meat is principally a means of generating economic income although it is also used in household consumption (Loibooki et al. 2012). The increasing demands on bush meat for income, vitality and cultural needs have therefore made bush meat trade a strong emerging economic and livelihood activity for both local and urban people.

Although in time past, hunting bush meat was primarily for household consumption as a source of protein, there is a paradigm shift from subsistence to commercial hunting for income nowadays (Ape Alliance, 1998; Fa et al. 2002; de Merode et al. 2004; Okiwelu et al. 2009). Cultural and social requirements affect consumption of bush meat (Kaltenborn et al. 2005) and people who have access to alternative incomes are less likely to hunt (Loibooki et al. 2012; Johannesen, 2005).

Unsustainable hunting has effects on ecosystem dynamics and therefore threatens the future of targeted species as well as the entire ecosystem (Apaza et al. 2002). This study was therefore carried out to assess the structure and reproduction based on hunters' returns, determine the species of animal harvested and the number foetus found in the carcasses.

\section{Material and Methods Study Area}

The study was conducted in Ogun-State which lies within the tropics and covers an area of $16,409.26 \mathrm{~km}^{2}$. It is bounded in the West by the Republic of Benin, in the South by LagosState and the Atlantic Ocean, in the East by OndoState and in the North by OyoState and OsunState. There are two distinct seasons in the state namely; the dry season and the wet season. The mean annual rainfall is between $129-132 \mathrm{~mm}$, temperature ranges between $25-29^{\circ} \mathrm{C}$ and the vegetation is evergreen rainforest (Balogun, 2000). Essentially, the study area is Top Brewery Bush meat Market in Abeokuta North Local Government Area. The 
Local Government headquarter is situated at Akomoje in Iberekodo area of the state capitalon coordinate.

\section{Methodology}

The materials used for the collection of data in this study were: weighing balance for measuring the weights of wild animals, sack for carrying and holding animals on weighing balance. On site market survey was employed for collection of information on animals. Each arrival was weighed before dissecting and dressing, and with the consent and efforts of the bush meat traders, each animal was clearly identified for name, source, packed inside a sack and weighed individually on the weighing balance. The following parameters were obtained from each animal; animal species scientific name, common name and local name; weight of the animal in kilogram; number of foetus; and locations where animals were hunted from. Information was collected twice in a week for a period of three months (13 weeks; March June). Data obtained were collated and analyzed using descriptive statistics, on Statistics Package for Social Science version 20 (SPSS).

\section{Results}

The total populations of animal species encountered during the study were 989 animals and were made up of twenty-two different species of animal which include mammals, reptiles and avian species. Mammals were mostly encountered in the study. The animal species with the highest frequency were Cane rat Thryonomys swinderianus (378) and Maxwell duiker Cephalophus maxwelli (259) while the least frequency was Short nose Crocodile Osteolamus tetraspis, Black cobra Maja melenoleuca and Tawny eagle Aquila rapax (Table 1).

The result of the age structure reveals the adult species having the highest population of 527 animals and accounted for $53.3 \%$, the highest percent. This is followed by the subadult age structure with a population of 314 animals and equivalent to $31.7 \%$. The juvenile age class had the least population of 148 animals representing $15 \%$ (Table 2).

Table 1. List of animal encountered

\begin{tabular}{|c|c|c|c|c|c|}
\hline $\begin{array}{l}\text { S/ } \\
\text { No }\end{array}$ & $\begin{array}{l}\text { Common } \\
\text { Name }\end{array}$ & $\begin{array}{l}\text { Scientific } \\
\text { Name }\end{array}$ & $\begin{array}{l}\text { Local } \\
\text { Name }\end{array}$ & $\begin{array}{l}\text { Frequ } \\
\text { ency }\end{array}$ & $\begin{array}{l}\text { Perce } \\
\text { ntage }\end{array}$ \\
\hline 1 & Canerat & $\begin{array}{l}\text { Thryonomys } \\
\text { swinderianus }\end{array}$ & Oya & 378 & \\
\hline 2 & Bushbuck & $\begin{array}{l}\text { Tragelaphus } \\
\text { scriptus }\end{array}$ & $\begin{array}{l}\text { Igala/ } \\
\text { Agbonrin }\end{array}$ & 20 & 38.2 \\
\hline 3 & $\begin{array}{l}\text { Maxwell } \\
\text { duiker }\end{array}$ & $\begin{array}{l}\text { Cephalophus } \\
\text { maxwelli }\end{array}$ & Etu & 259 & 2.0 \\
\hline 4 & Giant rat & $\begin{array}{l}\text { Cricetomys } \\
\text { gambianus }\end{array}$ & Okete & 73 & 26.2 \\
\hline 5 & $\begin{array}{l}\text { Red patas } \\
\text { monkey }\end{array}$ & $\begin{array}{l}\text { Erythrocebus } \\
\text { patas }\end{array}$ & Obo & 4 & 7.4 \\
\hline 6 & $\begin{array}{l}\text { Gabon } \\
\text { viper }\end{array}$ & $\begin{array}{l}\text { Bitis } \\
\text { gabonica }\end{array}$ & Oka & 15 & 0.4 \\
\hline 7 & $\begin{array}{l}\text { Monit or } \\
\text { lizard }\end{array}$ & $\begin{array}{l}\text { Veranus } \\
\text { niloticus }\end{array}$ & $\begin{array}{l}\text { Alegba/ } \\
\text { Anta }\end{array}$ & 21 & 1.5 \\
\hline 8 & Puff adder & Bitis arietans & $\begin{array}{l}\text { Mona } \\
\text { mona }\end{array}$ & 15 & 2.1 \\
\hline 9 & Hares & $\begin{array}{l}\text { Lepus } \\
\text { capensis }\end{array}$ & Ehoro & 81 & 1.5 \\
\hline 10 & $\begin{array}{l}\text { Ground } \\
\text { squirrel }\end{array}$ & $\begin{array}{l}\text { Xerus } \\
\text { erythropus }\end{array}$ & Ikun & 24 & 8.2 \\
\hline 11 & Genet Cat & $\begin{array}{l}\text { Genetta } \\
\text { pardina }\end{array}$ & $\begin{array}{l}\text { Ologbo } \\
\text { igbo }\end{array}$ & 7 & 2.4 \\
\hline 12 & Bush fowl & $\begin{array}{l}\text { Francolinus } \\
\text { bicalcaratus }\end{array}$ & Aparo & 34 & 0.7 \\
\hline 13 & $\begin{array}{l}\text { Guinea } \\
\text { fowl }\end{array}$ & $\begin{array}{l}\text { Numidea } \\
\text { meleagris }\end{array}$ & Awo & 11 & 3.4 \\
\hline 14 & Pangolin & $\begin{array}{l}\text { Mani } \\
\text { tetradactyla }\end{array}$ & Aaka & 18 & 1.1 \\
\hline
\end{tabular}

\begin{tabular}{c|l|l|l|c|c}
\hline 15 & Tree hyrax & $\begin{array}{l}\text { Dendrohyrax } \\
\text { dorsalis }\end{array}$ & $\begin{array}{l}\text { Owawa/ } \\
\text { ofafa }\end{array}$ & 1 & 1.8 \\
\hline 16 & Kob & Kobus kob & Egbin & 1 & 0.1 \\
\hline 17 & Black cobra & $\begin{array}{l}\text { Maja } \\
\text { melenoleuca }\end{array}$ & Agbadu & 12 & 0.1 \\
\hline 18 & $\begin{array}{l}\text { Dwarf } \\
\text { crocodile }\end{array}$ & $\begin{array}{l}\text { Osteolaemus } \\
\text { tetraspis }\end{array}$ & Ooni & 4 & 1.2 \\
\hline 19 & $\begin{array}{l}\text { Black } \\
\text { duiker }\end{array}$ & $\begin{array}{l}\text { Cephalophus } \\
\text { niger }\end{array}$ & Ekulu & 1 & 0.4 \\
\hline 20 & Mongoose & $\begin{array}{l}\text { Crossarchas } \\
\text { obscurus }\end{array}$ & Ijakumo & 2 & 0.1 \\
\hline 21 & $\begin{array}{l}\text { Giant forest } \\
\text { squirrel }\end{array}$ & $\begin{array}{l}\text { Protoxenus } \\
\text { strangeri }\end{array}$ & Okere & 4 & 0.2 \\
\hline 22 & $\begin{array}{l}\text { Tawny } \\
\text { eagle }\end{array}$ & Aquila rapax & Asa & 4 & 0.4 \\
\hline & Total & & & 989 & 100 \\
\hline
\end{tabular}

The results from the adjusted hypsometric models indicated a parabolic model (Table 2) best represents the relationship between DBH and height in the study area. We then used the model to estimate the height of trees not measured in the survey. It is important to note that we recommend the use of this model only for trees with a diameter range similar to that included in this study.

Table 2. Sexes and age structure of the animal species

\begin{tabular}{llcc}
\hline Variables & & Frequency & Percentage \\
\hline \multirow{2}{*}{ Sex } & Male & 431 & 43.6 \\
& Female & 558 & 56.4 \\
& Total & 989 & 100.0 \\
\hline Age & Adult & 527 & 53.3 \\
& Sub-adult & 314 & 31.7 \\
& Juvenile & 148 & 15.0 \\
& Total & 989 & 100
\end{tabular}

In Cane rat population, the study reveals that female (53.7\%) Cane rat were killed more than the male (46.3\%). The results of the sex ratio within the age group show that adult Cane rat was killed more than the sub-adult and the juvenile. The percentage sex ratio of male within the age group was $30.2 \%, 10.3 \%$ and $5.8 \%$ for adult, sub-adult and juvenile respectively, while the percentage sex ratio of the female within the age class were $19.3 \%, 15.6 \%$ and $18.8 \%$ for adult, sub-adult and juvenile respectively (Table 3). 
Yisau et al.

Table 3. The sex-age relationship of animal species

\begin{tabular}{|c|c|c|c|c|c|}
\hline Animal Species & Sex & Adult & Sub-adult & Juvenile & Total \\
\hline \multirow[t]{3}{*}{ Cane rat } & Male & $114(30.2)$ & $39(10.3)$ & $22(5.8)$ & $175(46.3)$ \\
\hline & Female & $73(19.3)$ & $59(15.6)$ & $71(18.8)$ & $203(53.7)$ \\
\hline & Total & $187(49.5)$ & $98(25.9)$ & 93 (24.6) & $378(100)$ \\
\hline \multirow[t]{3}{*}{ Bush buck } & Male & $6(31.6)$ & $4(21.0)$ & $0(-)$ & $1.0(52.6)$ \\
\hline & Female & $5(26.3)$ & $3(10.5)$ & $2(10.5)$ & $10(47.4)$ \\
\hline & Total & $11(57.4)$ & $7(31.6)$ & $2(10.5)$ & $20(100)$ \\
\hline \multirow[t]{3}{*}{ Maxwell duiker } & Male & $7(28.2)$ & $17(6.6)$ & $7(2.7)$ & $97(37.5)$ \\
\hline & Female & $117(45.2)$ & $13(12.7)$ & $12(4.6)$ & $162(62.5)$ \\
\hline & Total & $190(73.4)$ & $50(19.3)$ & $19(7.3)$ & $259(100)$ \\
\hline \multirow[t]{3}{*}{ Giant rat } & Male & $17(23.3)$ & $14(19.2)$ & $2(2.7)$ & $33(45.2)$ \\
\hline & Female & $19(26.0)$ & $15(20.5)$ & $6(8.2)$ & $40(54.8)$ \\
\hline & Total & $36(49.3)$ & $29(39.7)$ & $8(11.0)$ & $73(100)$ \\
\hline \multirow[t]{3}{*}{ Red Patas monkey } & Male & $1(25.0)$ & $1(25.0)$ & $-(-)$ & $2(50.0)$ \\
\hline & Female & $2(50.0)$ & $-(-)$ & $-(-)$ & $2(50.0)$ \\
\hline & Total & $3(75.0)$ & $1(25.0)$ & $-(-)$ & $4(100)$ \\
\hline \multirow[t]{3}{*}{ Gabon viper } & Male & $1(6.7)$ & $4(26.7)$ & $0(0.0)$ & $5(33.3)$ \\
\hline & Female & $5(33.3)$ & $4(26.6)$ & $1(6.7)$ & $10(66.7)$ \\
\hline & Total & $6(40.0)$ & $8(53.3)$ & $1(6.7)$ & $15(100)$ \\
\hline \multirow[t]{3}{*}{ Monit or lizard } & Male & $4(19.0)$ & $5(23.8)$ & $2(9.5)$ & $11(52.4)$ \\
\hline & Female & $4(19.0)$ & $6(28.6)$ & $0(0.0)$ & $10(47.6)$ \\
\hline & Total & $8(38.0)$ & $11(52.4)$ & $2(9.5)$ & $21(100)$ \\
\hline \multirow{3}{*}{ Puff Adder } & Male & $2(13.3)$ & $5(33.3)$ & $-(-)$ & $7(46.7)$ \\
\hline & Female & $4(26.7)$ & $4(26.7)$ & $-(-)$ & $8(53.3)$ \\
\hline & Total & $6(40.0)$ & $9(60.0)$ & $-(-)$ & $15(100)$ \\
\hline \multirow[t]{3}{*}{ Hares } & Male & $14(17.3)$ & $14(17.3)$ & $3(3.7)$ & $31(38.3)$ \\
\hline & Female & $18(22.2)$ & $29(35.8)$ & $3(3.7)$ & $50(61.7)$ \\
\hline & Total & $32(39.5)$ & $43(53.1)$ & $6(7.4)$ & $81(100)$ \\
\hline \multirow[t]{3}{*}{ Ground squirrel } & Male & $-(-)$ & $3(75.0)$ & $1(75.0)$ & $4(100)$ \\
\hline & Female & $-(-)$ & $-(-)$ & $-(-)$ & $-(-)$ \\
\hline & Total & $-(-)$ & $3(75.0)$ & $1(75.0)$ & $4(100)$ \\
\hline \multirow{3}{*}{ Gen } & Male & $2(28.6)$ & $1(14.3)$ & $-(-)$ & $3 \quad(42.9)$ \\
\hline & Female & $4(57.1)$ & $-(0.0)$ & $-(-)$ & $4(57.1)$ \\
\hline & Total & $6(85.7)$ & $1(14.3)$ & $-(-)$ & $7(100.0)$ \\
\hline \multirow[t]{3}{*}{ Bush fowl } & Male & $2(5.9)$ & $9(26.5)$ & $5(-)$ & $16(42.9)$ \\
\hline & Female & $3(8.8)$ & $12(35.3)$ & $3(8.8)$ & $18(52.9)$ \\
\hline & Total & $5(14.7)$ & $21(61.8)$ & $8(23.5)$ & $34 \quad(100.0)$ \\
\hline \multirow[t]{3}{*}{ Guinea fowl } & Male & $5(45.5)$ & $2(18.2)$ & $-(-)$ & $7 \quad(63.6)$ \\
\hline & Female & $3(27.3)$ & $1(9.1)$ & $-(-)$ & $4 \quad(36.4)$ \\
\hline & Total & $8(72.7)$ & $3(27.3)$ & $-(-)$ & $11(100.0)$ \\
\hline Pangolin & Male & $5(20.8)$ & $5(20.8)$ & $1(4.2)$ & 11 \\
\hline & Female & $4(16.7)$ & $7(29.2)$ & $2(8.3)$ & $13(54.2)$ \\
\hline & Total & $9(37.5)$ & $12(50.0)$ & $3(12.5)$ & 24 (100) \\
\hline Tree hyrax & Male & $5(27.8)$ & $2(11.1)$ & $0(0.0)$ & $7 \quad(38.9)$ \\
\hline & Female & $5(27.8)$ & $3(16.7)$ & $3(16.7)$ & 11 \\
\hline & Total & $10(55.6)$ & $5(27.8)$ & $3(16.7)$ & $18(100.0)$ \\
\hline Kob & Male & $-(-)$ & $1(100.0)$ & $-(-)$ & $1(100.0)$ \\
\hline & Female & $1(-)$ & $-(-)$ & $-(-)$ & $1 \quad(-)$ \\
\hline & Total & $1(-)$ & $1(100.0)$ & $-(-)$ & $2(100.0)$ \\
\hline Black Cobra & Male & $-(-)$ & $-(-)$ & $-(-)$ & $-\quad(-)$ \\
\hline & Female & $-(-)$ & $1(100.0)$ & $-(-)$ & $1(100.0)$ \\
\hline & Total & $-(-)$ & $1(100.0)$ & $-(-)$ & $1(100.0)$ \\
\hline Short nose Crocodile & Male & $-(-)$ & $1(100.0)$ & $-(-)$ & $1 \quad(100.0)$ \\
\hline & Female & $-(-)$ & $-(-)$ & $-(-)$ & $-\quad(-)$ \\
\hline & Total & $-(-)$ & $1(100.0)$ & $-(-)$ & $1 \quad(100.0)$ \\
\hline Crowned duiker & Male & $1(8.3)$ & $2(16.7)$ & $1(8.3)$ & $4(33.3)$ \\
\hline & Female & $4(33.3)$ & $3(25.0)$ & $1(8.4)$ & $8(66.7)$ \\
\hline & Total & $5(41.6)$ & $5(41.7)$ & $2(16.7)$ & $12(100.0)$ \\
\hline GiantForest Squirrel & Male & $1(25.0)$ & $-(50.0)$ & $-(-)$ & $3 \quad(75)$ \\
\hline & Female & $-(-)$ & $1(25.0)$ & $-(-)$ & $1(25)$ \\
\hline & Total & $1(25.0)$ & $1(75.0)$ & $-(-)$ & $4(100)$ \\
\hline Tawny Eagle & Male & $-(-)$ & $2(-)$ & $-(-)$ & $-\quad(-)$ \\
\hline & Female & $1(100)$ & $1(-)$ & $-(-)$ & $1(100.0)$ \\
\hline & Total & $1(100)$ & $3(-)$ & $-(-)$ & $1 \quad(100.0)$ \\
\hline Mongoose & Male & $2(50.0)$ & $-(0.0)$ & $-(-)$ & $2 \quad(50)$ \\
\hline & Female & $1(25.0)$ & $1(25.0)$ & $-(-)$ & $2 \quad(50)$ \\
\hline & Total & $3(75.0)$ & $1(25.0)$ & $-(-)$ & $4 \quad(100.0)$ \\
\hline
\end{tabular}

Note: Figures in parenthesis are percentages. 
In the Bushbuck age class, adult females and males accounted for the highest population of $57.9 \%$ this revealed that adult Bushbuck was more killed than the sub-adult and juvenile. The same result was observed in the Maxwell duiker population where the adult males and females population accounted for $73.4 \%$ while the sub-adult and juvenile was $19.3 \%$ and $7.3 \%$ respectively.

Giant rat population shows that the most hunted age-sex class was the adult males and females which accounted for $49.3 \%$ followed by sub-adult $39.7 \%$ and $11 \%$ respectively. Red patas monkey population, both the male adult and sub-adult had $25 \%$ each and the female adult was $50 \%$ of the whole population. In all, the female adult was the highest with $75 \%$. Gabon viper population, the sub-adult males and females were most hunted with $53.3 \%$ of the population. Monitor Lizard had the same pattern having the subadult has most hunted with $52 \%$. In the Puff adder population, males and females sub-adult was the most hunted having $60 \%$ of the population.

Genet cat male adult and sub-adult were only recorded with $28.6 \%$ and $14.3 \%$ respectively, while the male adult has the highest. The female adult was the only age class obtained with $57.1 \%$. In all, adult male had the highest with $85.7 \%$. Pangolin male adult, sub-adult and juvenile were $20.8 \%, 20.8 \%$ and $4.2 \%$ respectively. The highest populations were from adult and sub-adult. The female adult, sub-adult and juvenile were $16.7 \%, 29.2 \%$ and $8.3 \%$ respectively with the sub-adult having the highest population. The sub-adult and females were the highest with $50 \%$.

The Tree hyrax had only male adult and sub-adult which were $27.8 \%$ and $11.1 \%$ with the adult population emerged the highest. The female adult, sub-adult and juvenile were $27.8 \%, 16.7 \%$ and $16.7 \%$. In all, males and females adult were the highest with $55.6 \%$.

The population of Kob, Black cobra and Short nose Crocodile had only one age class obtained. Kob had one sub-adult, Black cobra had one female subadult and the crocodile had one male adult with each at $100 \%$.

Mongoose male adult population recorded 50\%, while the female adult and sub-adult were $25 \%$ each. The males and females adult were the highest with $75 \%$. Tawny eagle recorded only a female adult.

The results of the animals returned by the hunters according to sources indicate that Tibo and Gingbin community was where the highest number of animals were hunted with $157(15.9 \%)$ and $151(15.3 \%)$ of animals respectively. These were followed by Abulaje (149), Akesan (144) and Elugu (140) representing $15.1 \%, 14.6 \%$ and $14.1 \%$ of animals respectively. The least number of animals recorded was 8 representing $0.8 \%$ from Oba community (Table 4 ).

Table 4. Frequency and percentages of animals according to sources of supply.

\begin{tabular}{lcl}
\hline Source $(\mathbf{s})$ & Frequency & Percent (\%) \\
\hline Akesan & 144 & 14.6 \\
Abulaje & 149 & 15.1 \\
Olorunda & 134 & 13.5 \\
Elugu & 140 & 14.1 \\
Ekeku & 106 & 10.7 \\
Tibo & 157 & 15.9 \\
Oba & 8 & 0.8 \\
Gbingbin & 151 & 15.3 \\
\hline Total & 989 & 100.0 \\
\hline
\end{tabular}

The result of the mean weight and the mean number of foetus indicates that the Cane rat population has the mean weight of the least species to be $1.85 \mathrm{~kg}$ and the highest to be $4.85 \mathrm{~kg}$ while the mean number of foetus for the least species is $2.73 \mathrm{~kg}$ and the highest is $4.07 \mathrm{~kg}$. Bush buck has the least to be $8.02 \mathrm{~kg}$ and the highest mean weight to be $24.22 \mathrm{~kg}$. The mean number of foetus of the least animal is $0.81 \mathrm{~kg}$ and the highest is $1.85 \mathrm{~kg}$ (Table 5). Table 6 shows the result of the mean weight of the animals according to sex. In Cane rat population the highest mean weight of male is $5.76 \mathrm{~kg}$ with the least mean weight is $3 \mathrm{~kg}$, while the highest mean weight of female is $4.85 \mathrm{~kg}$ and the least is $1.93 \mathrm{~kg}$. The male animal has more weight than the female. For the Bush buck population the lowest mean weight in female is $14.2 \mathrm{~kg}$ and the highest mean of $31.68 \mathrm{~kg}$. The highest mean weight is $24.22 \mathrm{~kg}$ and lowest of $8.34 \mathrm{~kg}$. Maxwell duiker has the highest mean weight in the male and female to be $6.28 \mathrm{~kg}$ and $7.26 \mathrm{~kg}$ respectively and the lowest mean weight in the male and female are $3.76 \mathrm{~kg}$ and $3.88 \mathrm{~kg}$ respectively. Kob has mean weight value only for male as $20.0 \mathrm{~kg}$ in the highest and lowest order. In the crocodile population the highest weight of male animal is $19.0 \mathrm{~kg}$ and the lowest also $19.0 \mathrm{~kg}$ without female mean weight. (Table 6)

The total number of foetus recorded was 342 and accounted for the reproductive status of the populations. Cane rat had highest reproductive status of 209 foetus followed by Maxwell duiker with 103 foetus. Giant rat, Hares, Bushbuck, Pangolin and Crowned duiker have reproductive indices of 12, 7, 7 2 and 2 foetus respectively. 
Table 5. The mean weight and the mean number of foet us of the animals' species.

\begin{tabular}{lcc}
\hline Animal species & Mean weight $(\mathrm{kg})$ & $\begin{array}{c}\text { Mean number of } \\
\text { foetus }(\mathrm{kg})\end{array}$ \\
\hline Canerat & $3.85 \pm 1.50$ & $3.40 \pm 0.67$ \\
Bush buck & $16.12 \pm 8.10$ & $1.33 \pm 0.52$ \\
Maxwell duiker & $5.36 \pm 1.56$ & $1.15 \pm 0.42$ \\
Giant rat & $1.68 \pm 0.75$ & $3.00 \pm 0.00$ \\
Red patas monkey & $7.25 \pm 1.32$ & - \\
Gabon viper & $2.07 \pm 0.73$ & - \\
Monitor lizard & $3.09 \pm 1.49$ & - \\
Puff adder & $2.30 \pm 1.09$ & - \\
Hares & $1.66 \pm 0.60$ & $3.50 \pm 0.70$ \\
Ground squirrel & $0.95 \pm 0.10$ & - \\
Genet cat & $1.07 \pm 0.18$ & - \\
Bush fowl & $0.46 \pm 0.22$ & $2.00 \pm 0.00$ \\
Guinea fowl & $0.97 \pm 0.04$ & - \\
Pangolin & $2.56 \pm 1.04$ & $2.00 \pm 0.00$ \\
Tree hyrax & $3.47 \pm 1.11$ & - \\
Kob & $4.00 \pm 0.00$ & - \\
Black cobra & - & $2.50 \pm 0.00$ \\
Crowned duiker & $6.91 \pm 3.58$ & $1.00 \pm 0.00$ \\
Mongoose & $5.50 \pm 1.29$ & - \\
Giant forest squirrel & $1.12 \pm 0.25$ & - \\
Tawny eagle & $1.00 \pm 0.00$ & - \\
Short nose crocodile & - & $19.00 \pm 0.00$ \\
$\quad$ TO TAL & $3.39 \pm 2.94$ & $2.05 \pm 1.20$ \\
& &
\end{tabular}

Table 6. The mean weight of each animal species sex.

\begin{tabular}{lcl}
\hline Animal species & \multicolumn{1}{c}{ Male $(\mathrm{kg})$} & Female $(\mathrm{kg})$ \\
\hline Canerat & $4.38 \pm 1.38$ & $3.39 \pm 1.46$ \\
Bushbuck & $16.28 \pm 7.94$ & $22.94 \pm 8.74$ \\
Maxwell duiker & $5.02 \pm 1.26$ & $5.57 \pm 1.69$ \\
Giant rat 1. & $70 \pm 0.90$ & $1.67 \pm 0.60$ \\
Red patas monkey & $6.25 \pm 0.35$ & $8.25 \pm 1.06$ \\
Gabon viper & $1.90 \pm 0.74$ & $2.15 \pm 0.74$ \\
Monitor lizard & $2.90 \pm 1.80$ & $3.30 \pm 1.14$ \\
Puff adder & $2.00 \pm 1.15$ & $2.56 \pm 1.05$ \\
Hares & $1.56 \pm 0.54$ & $1.73 \pm 0.64$ \\
Ground squirrel & $0.95 \pm 0.10$ & \\
Genet cat & $1.17 \pm 0.29$ & $1.00 \pm 0.00$ \\
Bush fowl & $0.47 \pm 0.20$ & $0.46 \pm 0.23$ \\
Guinea fowl & $0.97 \pm 0.05$ & $0.98 \pm 0.05$ \\
Pangolin & $2.72 \pm 1.00$ & $2.42 \pm 1.09$ \\
Tree hyrax & $3.50 \pm 0.86$ & $3.45 \pm 1.29$ \\
Kob & $20.00 \pm 0.00$ & \\
Crocodile & $19.00 \pm 0.00$ & \\
Ground duiker & $5.50 \pm 2.64$ & $7.62 \pm 3.93$ \\
Mongoose & $5.50 \pm 0.70$ & $5.50 \pm 2.12$ \\
Giant forest squirrel $1.17 \pm 0.28$ & $1.00 \pm 0.00$ \\
Tawny eagle & & $1.00 \pm 0.00$ \\
Black Cobra & & $2.50 \pm 0.00$ \\
& & \\
& &
\end{tabular}

Table 7. Number of foetus extracted from the carcass per week

\begin{tabular}{|c|c|c|c|c|c|c|c|c|c|c|c|c|c|c|}
\hline \multirow{2}{*}{ Animal species } & \multicolumn{14}{|c|}{ Total number of foetus per week } \\
\hline & $\mathbf{W k W k}$ & & $\mathbf{W k 3}$ & $\mathbf{W k} 4$ & $\mathbf{W k 5}$ & Wk6 & Wk7 & Wk8 & $\mathbf{W k} \boldsymbol{9}$ & Wk10 & Wk11 & Wk12 & Wk13 & TOTAL \\
\hline Cane rat & 20 & 25 & 6 & 29 & 28 & 22 & 4 & 9 & 16 & 19 & - & 21 & 10 & 209 \\
\hline Maxwell duiker & 10 & 7 & 8 & 20 & 13 & 11 & 2 & - & 9 & 6 & 4 & 7 & 6 & 103 \\
\hline Bush fowl & - & - & - & & - & - & - & - & - & - & - & - & - & - \\
\hline Pangolin & - & - & - & 2 & - & - & - & - & - & - & - & - & - & 2 \\
\hline Giant rat- & - & - & - & - & - & - & - & 6 & - & 3 & 3 & - & 12 & \\
\hline Gabon viper & - & - & - & - & - & - & - & - & - & - & - & - & - & - \\
\hline Hares & 4 & - & - & - & 3 & - & - & - & - & - & - & - & - & 7 \\
\hline Monit or lizard & - & - & - & - & - & - & - & - & - & - & - & - & - & - \\
\hline Guinea fowl & - & - & - & - & - & - & - & - & - & - & - & - & - & - \\
\hline Bush buck & - & 2 & - & - & 1 & 1 & - & 2 & 1 & - & - & - & - & 7 \\
\hline Puff adder & - & - & - & - & - & - & - & - & - & - & -- & - & - & - \\
\hline Ground Squirre & - & - & - & - & - & - & - & - & - & - & - & - & - & - \\
\hline Red patas monkey & - & - & - & - & - & - & - & - & - & - & - & - & - & - \\
\hline Genet Cat & - & - & - & - & - & - & - & - & - & - & - & - & - & - \\
\hline Tree hyra & - & - & - & - & - & - & - & - & - & - & - & - & - & - \\
\hline Black cobra & - & - & - & - & - & - & - & - & - & - & - & - & - & - \\
\hline Short nose crocodile & - & - & - & - & - & - & - & - & - & - & - & - & - & - \\
\hline Crowned duiker & - & - & - & - & - & - & - & 1 & - & 1 & - & - & - & 2 \\
\hline Mongoose & - & - & - & - & - & - & - & - & - & - & - & - & - & - \\
\hline Tawny eagle & - & - & - & - & - & - & - & - & - & - & - & - & - & - \\
\hline Giant forest squirrel & - & - & - & - & - & - & - & - & - & - & - & - & - & - \\
\hline Kob & - & - & - & - & - & - & - & - & - & - & - & - & - & - \\
\hline TOTAL & 34 & & & 51 & $\overline{45}$ & $\overline{34}$ & $\overline{0}$ & & 30 & 26 & & $\overline{31}$ & 16 & $\overline{342}$ \\
\hline
\end{tabular}




\section{Discussion}

The study shows that more adult species harvested followed by sub-adults and juvenile. Anderson (1999) stated that age ratios may be influenced more by adult mortality than by new births. This pattern of hunters' returns would greatly have negative impact on the wild population, because the productive or the matured adults are continually been harvested, this would likely result in declination of the animal population especially the most hunted ones. Cleveland et al. (1982) succinctly stated that nearly every population has three ecological ages; pre-reproductive, reproductive and post-reproductive ages.

The study shows indiscriminate harvesting of wildlife, without regard for the age of the animal, this could be as a result of the high demand for bush meat. This view was also shared by Tee et al. (2012) which stated that as demand for bush meat consumption increases, hunting activities also increase to cope with the rising demand. This indiscriminate harvest would eventually lead to a decline in the wildlife resources. Many researchers have also corroborated the fact that the unrestrained pressure on the wildlife resources would eventually decrease their population in the wild and hence a collapse in their conservation (Bowen-Jones et al. 2003; Fa et al. 2003; Okiwelu et al. 2009).

The reproductive status of the study population was low according to Cleveland et al. (1982) that the ratio of the three age groups in a given population at any particular time is an index of the reproductive status of the population. In addition, this pattern of hunters' return was affirmed by Benette (2006) observation that unsuitable hunting for almost anything large enough to be eaten, potent enough to be turned into medicine, and lucrative enough to be sold is stripping wildlife from wild areas, leaving reserved forests, unreserved forest and communal woodlots empty of wildlife.

One-third of the total animals harvested were cain rat and over half of the harvested cain rat were female. This correlates with FAO (1989) survey of a market in Accra (Ghana) which revealed that cain rat was the most important wild animal species sold. Seventy five percent of bushmeat sold was from cain rat. Also Onadeko et al. (1998) in the study of 3bushmeat processing centers in Abeokuta, Nigeria stated that in terms of number killed per species, cain rat was the most abundant on each of the collection centers. Similar study conducted in Markurdi, Nigeria by Tee et al. (2012) also recorded higher number of cain rat harvested.

Generally, Cane rat, Bushbuck, Maxwell duiker, Giant rat, Red patas monkey, Genet cat, Guinea fowl, Tree hyrax, Tawny eagle and Mongoose, the males and females adult age class recorded the highest population of all the age classes while the population of Giant forest squirrel, Crowned duiker, Kob, Short nose crocodile, Black cobra, Pangolin, Bush fowl, Ground squirrel, Gabon viper, recorded their males and females sub-adult age classes with the highest percentage. Bennett (2006) stated that unregulated hunting and trade threaten the survival of many species, and also the livelihoods of rural people who depend on them for food or monetary benefit. Even though there are policy and regulations on harvesting of wild animal species, but enforcement is very poor.

The total number of foetus recorded (342) was more than one third of the carcass harvested and this depicts the reproductive status/potential of the populations. Cane rat also had highest reproductive status and number of foetus (209) followed by Maxwell duiker with 103 foetus. Anderson (1999) stated that Corpora lutea counts indicate ovulation rates and can be used in early gestation while embry o counts provide a more accurate estimate of litter size at birth and thus the population potential. In all, the numbers of animal species with that foetus were seven. The total number of foetus was observed to be lower than the population of killed animals by the hunters, which implies that there were fewer number of pregnant animal killed.

The rate of harvest of wildlife species (i.e the carcass recorded) was higher than the rate of reproduction (foetus) and this could bring about imbalance in the animal population. Effective protection and management has been a major obstacle in the actual practice of biodiversity conservation in Nigeria. This is in line with Onadeko et al. (1998), more so Onadeko et al. (1989) observed that a vast majority of people both in the rural, suburban and urban setting, are more concerned with what to consume rather than what to conserve. It is, therefore, recommended that wildlife law should be enforced, intervention on wildlife and conservation measures in the areas where wild animals are overexploited. There is also need for intensive literacy education and environmental enlightenment for the villagers living in the affected areas. This could help educate villagers in the affected areas on the importance of the wildlife resources and as well stimulate their support towards wildlife protection and conservation.

\section{Conclusion}

The study reveals that there is indiscriminate persecution of wild animals without consideration of their age class and sex, thus depleting the population of the animal. There is therefore need to control the harvesting of wild animal species, even though many of the animals were harvested outside protected area. Adequate environmental and conservation activities should also be done for people living around these areas.

\section{References}

Apaza, L. D., Wilkie, E., Byron, T., Huanca, W., Leonard, E., Pérez, V., Rey esGarcía, V. and Vadez, R.G. (2002). Meat prices influence the consumption of wildlife by the Tsimane' Amerindians of Bolivia, Ory x. 36: 382387.

Ape Alliance, (1998). The African bush meat trade- a recipe for extinction. Fauna and Flora International, Cambridge. $74 \mathrm{pp}$

Anderson, S. H. 1999. Managing our wildlife resources. Third edition. Prentice Hall, Upper Saddle River, New Jersey, USA.

Ayeni, J.S.O., Afolayan, T.A. and Ajayi, S.S. (1982). Introductory Handbook on NigeriaWildlife. Kainji Lake Research Institute. Pp. 80

Ay odele, I.A., Abe, A.J. and Olaniy an, A.O. (1999) Essentials of Zoo M anagement. Jachim, publishers, Ibadan, Oy o State, Nigeria, pp.1 - 34

Balogun, O. Y. (2003). Senior Secondary Atlas. $2^{\text {nd }}$ Ed. Longman Nigeria.

Bailey, A. J. (1984). Principle of Wildlife Management. Colorado State University. John Wiley \& Sons, New York.

Bennett, E. (2006). Wildlife Conservation: Bow Wow! African Wild Dogs- in the Wildand at the Bronx Zoo. Publication of Wildlife Conservation Society.

Bifarin, J. O., Ajibola, M.E. and Fadiyimu A. A. (2008). Analy sis of marketing bush meat in Idanre Local Government Area of Ondo State, Nigeria. African Journal of Agricultural Research Vol. 3 (10), pp. $667-$ 671. 
Bowen-Jones, E., Brown, D., and Robinson, E.J.Z. (2003). Economic commodity or environmental crises? An interdisciplinary approach to analy sing the bush meat trade in central and West Africa.Area 35. 4, 390-402.

Brashares J.S., Archase, P. and Sam, M.K. (2001). Human demography and reserve size Predict wildlife extinction in West Africa Proceedings of the royal society of London series B 268: 2473-2478.

Brashares, J.S., Arcese, P., Sam, M.K., Coppolillo, P.B., Sinclair, A.R.E. and Balmford, A. (2004). Bushmeat hunting, wildlife declines, and fish supply in West Africa. Science 306: 1180-1183.

Cleveland, P. H., Jr. Larry, S. R. and Frances, M. H. (1982).Biology of Animals $3^{\text {rd }}$ Edition. The C.V. Mosby Company Pg. 507-579.

Dasmann, R.F. (1981). Wildlife Biology. Second Edition. John Wiley and sons, Inc. New York .

deMerode, E., Homewood, K. and Cowlishaw, C. (2003). 'The value of bush meat and wild foods to rural households living in extreme poverty in the Eastern democratic Republic of Congo' draft, University College London.

deMerode, E., Katherine H. and Guy, C. (2004). The value of bush meat and other wild foods to rural households living in extreme poverty in Democratic Republic of Congo. Biological Conservation. 118, 573-581

Fa, J. and Yuste, J.G. (2001). Commercial bushmeat hunting in the Monte mitra forests. Equatorial Guinea: extent and impact. Animal Biodiversity and Conservation 24: 31-52.

Fa, J.E., Peres, C.A. and Meeuwig, J. (2002). Bush meat exploitation in tropical forests: an intercontinental comparison. Conservation Biology 16 (1), 232-237.

Fa, J.E., Dominic, C. and Meeuwig, J. (2003). Bush meat and food security in the Congo Basin: linkages between wildlife and people's future. Environmental Conservation 30, 1: 71-78.

Food and Agriculture Organisation, (1989). Forest and Food Security. Rome Italy. FAO. 1989, FAOForest Paper No 90.

Guy, C., Samanthe, M. and Rowcliffe, J.M. (2005). Structure and Operation of a Bush Meat Commodity Chain in Southwestern Ghana: Conserv. Biol. Vol. 19, No. 1, pp. 139-149

Holmern, T., Mkama, S., Muya, J. and Roskaft, E. (2006). Intraspecific prey choice of bushmeat hunters outside the Serengeti National Park, Tanzania: a preliminary analy sis. African Zoology 41: 81- 87.

Holmern, T., Muya, J. and Roskaft, E. (2007). Local law enforcement and illegal bushmeat hunting outside the Serengeti National Park, Tanzania. Environmental Conservation 34: 55-63.

Johannesen, A.B. (2005). Wildlife conservation policies and incentives to hunt: an empirical analy sis of illegal hunting in western Serengeti, Tanzania. Environment and Development Economics 10: 271- 292.

Kaltenborn, B.P., Ny ahongo, J.W. and Tongstad, K.M. (2005). The nature of hunting around the western corridor of Serengeti national park, Tanzania. European Journal of Wildlife Research 51: 213- 222.
Kiringe, J.W., Okello, M.M. and Ekajul, S.W. (2007). Managers' perceptions of threats to the protected areas of Kenya: prioritization for effective management. Oryx 41: 314-321.

Loibooki, M., Hofer, H., Campbell, K.L.I. and East, M.L. (2002). Bush meat hunting by communities adjacent to the Serengeti National Park, Tanzania: the importance of livestock ownership and alternative sources of protein and income. Environmental Conservation, 29: 391-398.

Lwanga, J.S. (2006). The influence of forest variation and possible effects of poaching on duiker abundance in Ngogo, Kibale National Park, Uganda. African Journal of Ecology 44: 209-218.

Ndibalema, V.G. and Songorwa, A.N. (2007). Illegal meat hunting in Serengeti: dynamics in consumption and preferences. African Journal of Ecology 46: 311-319.

Ny ahongo, J.W., Holmern, T., Kaltenborn, B.P. and Roskaft, E. (2009). Spatial and temporal variation in meat and fish consumption among people in the western Serengeti, Tanzania: the importance of migratory herbivores. Oryx 43: 258-266.

Oates, J.F., Abedi-Lartey, M., Megraw, W.S., Struhsaker, T.T. and Whilosides, G.H. (2000). Extinction of a West African Red Colobus Monkey: Conserv. Biol. 14: 1526-1532.

Ogogo, A.U. (2004) Wildlife Management in Nigeria, Objectives, Principles and Procedures. 1st Edition, Median Communications, Calabar. Pp 134 - 154

Okiwelu, S.N., Ewurum, N. and Noutcha, M.A.E. (2009). Wildlife harvesting and bush meat trade in River State, Nigeria: species composition, seasonal abundance and cost. Scientia Africana 8, 1-8.

Olupot, W., Mcneilage, A.J. and Plumptre, A.J. (2009). An analy sis of socioeconomics of bushmeat hunting at major hunting sites in Uganda. Wildlife Conservation Society, working paper number 38 .

Onadeko, S.A. (1997). Sex and Age Distribution of the Grasscutter (ThryonomysswinderianusTemminck). Journal of Tropical Forest Resources Vol. 13 (1997) pp 9-15.

Onadeko, S.A., Adegboola, P.O. and Oladoyinbo O.O. (1989). Consumptive Utilization of Wildlife Resources in OyoState. Proc 1989 Biennial Conference. ECOSON. Okaeme A.N. (Ed) $223-235$

Onadeko, S.A., Inah, E.I. and Shotuyo, A.L.A. (1998). Bushmeat Consumption and Biodiversity Conservation. Biodiversity of the Rainforest Ecosystem in Nigeria. A Colloquium organized by FEPA-UNAAB Linkage Centre for Forest, Conservation and Biodiversity. $8^{\text {th }}-10^{\text {th }}$ December, 1998. O. A. Adeola J. Okogie and L. O. Ojo (Ed.)Pp 247-263

Rist, J., Rowcliffe, M., Cowlishaw, G. and MilnerGulland, E.J. (2008). Evaluating measures of hunting effort in a bushmeat system. Biological Conservation 141: 2086-2099.

Tee, T.N., Ikpa, T.F. and Tortange, V. (2012). Bushmeat trade in Makurdi metropolis; Implications for the conservation of wildlife in Nigeria. Journal of Applied Biosciences52: 3704 - 3715 
Thirgood, S., Mosser, A., Tham, S., Hopcraft, G.,

Mwangomo, E., Mlengey a, T., Kilewo, M., Fry xell, J.,

Sinclair, A.R.E. and Borner, M. (2007). Can parks

protect migratory ungulates? The case of the Serengeti

wildebeest. Animal Conservation 7: 113-120.

Waite, T.A. (2007). Revisiting evidence for sustainability of bushmeat hunting in West Africa. Environmental Management 40: 476-480. 